\title{
The Critical Level of Mangrove Ecosystem in Lariang Watershed Downstream, West Sulawesi-Indonesia
}

\author{
Naharuddin Naharuddin \\ Department of Forestry, Faculty of Forestry, Tadulako University, Palu 94118, Indonesia
}

Corresponding Author Email: nahar.pailing@gmail.com

https://doi.org/10.18280/ijsdp.160505

Received: 25 May 2021

Accepted: 30 July 2021

\section{Keywords:}

critical level, mangrove ecosystem, photogrammetric, terrestrial, watershed, west Sulawesi

\begin{abstract}
Critical land is a land whose soil condition has experienced or is in the process of physical, chemical, or biological damage which ultimately endangers hydrological, orological functions, and agricultural production. This research purposes were to determine the level of criticality of mangrove ecosystems, as the basis for sustainable management. Determination and delineation of the location were carried out photogrammetrically using Landsat 7 ETM + Band 542 imagery and maps, as well as terrestrial by direct measurement in the field. The species inventory and identification, tree/pole potency, saplings and seedlings used the line plot sampling and spot check methods. The results showed that the mangrove ecosystem area was of 577.07 ha, condition of dense (uncritical) vegetation reached an area of 138.16 ha $(23.94 \%)$, followed by a rare (critical) condition of 286.63 ha (49.67\%), while a damaged condition (very critical) 152.28 ha $(26.39 \%)$. The dominant mangrove species were Sonneratia alba, Rhizophora apiculata, Avicenia marina, and Rhizophora mucronata. The main determinant of the mangrove ecosystems criticality was the mangrove cover area reduction as the nonmangrove land (ponds) impacts. To improve the quality of mangrove forest ecosystems, sustainable conservation is needed, one of which is the preparation of basic mangrove critical data and community empowerment. They are needed to restore, maintain and improve the function of forests and mangrove forest lands in order to increase their carrying capacity, productivity and their role in maintaining life support systems through rehabilitation programs.
\end{abstract}

\section{INTRODUCTION}

Mangroves, a natural resource, provide a variety of ecosystem services (ES) [1, 2]. ES include food services, medicine, climate control, coastal abrasion, protection against hurricanes, etc. [3, 4]. The existence of mangroves helps in human life, especially in coastal areas. Anthropogenic pressures from various needs have led to a decrease in mangrove forest cover around the world [5-17].

The mangrove ecosystems had a strategy function for the organism life [18, 19]. Land-use change and conversion of mangrove land from would change the organism life function. One of the land and forest conversion impacts in mangrove forests was the critical land occurrence. Critical land was a relationship from the climate, biological, physical, land, and human resources aspects. Land in watersheds became critical if it was used beyond its ecological capacity, inappropriate allocation of land use, weak effectiveness of natural resource management controls, very high intensity of management. so that critical land can be minimized, sustainable management is needed [20]. According to Mubarokah et al. [21] a good quality watershed used wisely to provide a decent living for the population around it and could provide direct or indirect benefits.

Critical land was unproductive land because its management did not pay attention to conservation principles, so that the land was damaged, lost or reduced in function to a predetermined or expected limit [22]. The damages mangrove ecosystems effects were pollutants or contaminants originating from heavy metal industry waste [23-25].

In addition, to the land-use intensity and population pressure factors of income per capita and the security level of land tenure also affected the land criticality level. Land use and land cover changes were the basis for the land criticality level assessing [26-28].

Land if used was not following its designation, especially in protected areas and agricultural cultivation areas would have a high level of land criticality that could reduce its role in the interests of protecting and improving people's welfare [29].

The coastal areas management should be carried out wisely which was an integral part of the watershed management form. Human activities in watersheds in the agriculture, fishery, plantation, forestry, tourism and other sectors which pay less attention to ecological aspects could cause the environmental degradation and the critical land.

An important function of mangrove ecosystems was as a chain that connected marine and terrestrial ecosystems (downstream watershed areas). Mangrove forests produced large amounts of organic material, especially litter. Mangrove litter was an important source of organic material in the food chain in the mangrove forest. The litter would decompose due to microorganism activity. This decomposition result would be the phytoplankton nutrition source which as a primary producer position and then zooplankton utilized phytoplankton as the main energy source, which as a primary consumer position [30]. Mangrove ecosystems could be as 
biofilter function as well as binding agents and pollution traps [31]. Mangroves area were also a place to live various types of gastropods, fish, detritus-eating crabs and bivalves then the plankton-eating fish, so that mangroves function was as the natural biofilter [32].

Research on the criticality level of mangroves as a basis for management has not been done much. The research is only focused on the problem the vegetation structure of mangrove forests [33, 34], the impact of wod harvesting on the structure and composition of mangrove forest vegetation [35], The role of mangroves in inundating water during storms [36]. Mapping the structure of mangrove forests using satellite imagery [37].

The mangrove ecosystem area in the Lariang watershed downstream had been degraded from year to year. One of the degradation drivers which namely the mangrove forest land conversion into agricultural areas, plantations and settlements. Most of the converted mangrove ecosystem land was used as oil palm plantations, both private and state. The mangrove land conversion was based on the increasing of land need which followed by population growth increasing. This situation could be found in almost most coastal areas downstream of the Lariang watershed.

To protect and guarantee the mangrove ecosystem sustainability in the Lariang watershed, it was necessary to conduct the evaluating research to the mangrove ecosystems critical level in the Lariang downstream watershed, West Sulawesi, as a basis for mangrove ecosystem management policies. Other than that, in order to preserve mangroves through increasing ecological, economic and social functions as renewable natural resources, the main focus that is important is to provide data on the criticality of mangroves, so that rehabilitation planning and sustainable forms of mangrove forest management can be carried out in order to meet the needs of future generations as a form of environmentally sustainable development.

The objective of this study was to determine the critical level of mangrove in Lariang downstream watershed, West Sulawesi, as a basis for sustainable mangrove ecosystem management.

\section{LITERATURE REVIEW}

\subsection{Mangrove forest as ecosystem services}

Mangrove forest produces goods and services that can be used directly or indirectly, it can also produce ecosystem services for the environment that provide benefits in other forms such as ecotourism benefit such beauty, tranquility and can be more beneficial in the long term [38]. The benefits of mangrove forest as flood prevention areas and spawning grounds fish and crab. These benefits are known as the ecological benefit that is often not quantified in a comprehensive calculation of the value of the resource [39].

Mangroves is one of the most important coastal ecosystem because it supports many ecosystem services. Although mangrove forest has decreased biodiversity due to exploitation, mangrove forest still provides various ecosystem services for communities in coastal areas [40]. Mangrove provides ecosystem services in the form of economic benefits and food security [41].

Ecotourism-based ecosystem service provides a good solution for conservation and protection and sustainable use of coastal ecosystems. According to Chakraborty et al. [38] the implications of mangrove forest management as a form of ecosystem service can be based on four interrelated things, namely: (1) increasing awareness of local culture and related local ecological knowledge collection that ensures sustainable resource; (2) consideration of non-economic assessment of nature tourism (recreation) related to the lifestyle of indigenous and local communities, more importantly the socio-ecological relationship; (3) better understanding of the ecosystem services exchange; (4) combine the recreational values of local communities and tourism in enhancing the ecosystem services from the landscape.

\subsection{Overview of critical land}

The Land resource is one of natural resources that plays important role in the agricultural production process, including livestock and forestry [42]. The parameters of land resources include soil, climate and water, topography, and vegetation including grasslands and forests. Therefore, any activity that changes natural resources including landscapes for development such as agriculture, ponds, mining, industry, housing, infrastructure can cause damage to land resources and decrease productivity and can increase the potential for critical land. Various land and soil properties are used as indicators of critical land [43]. Indicator of species diversity [44]. climate change, urbanization and pollution are one part of accelerating critical land [45]. Abrasion, hydrological damage, deforestation, siltation, and land conversion for cultivation and ponds and other land uses in mangrove forest area causes critical mangrove forests [46].

Land is one of natural resources component that plays role in agricultural production such as livestock and forestry that includes climate and water resources, land surface forms, soil, and vegetation including grasslands and forests [47]. Soil is earth surface or the top layer of the earth crust that is very thin, generally less than 2 meters it, has certain characteristics or properties, and is a place for plant roots, vegetation and trees to grow. Critical land is incapable land that has experienced the damage of physical, chemical, and biological process that endangers the hydrological, orological functions, agricultural production, settlements and socio-economic life of the affected area. Critical land as not functional land as a medium for regulating water systems and elements of good agricultural production is characterized by vegetation cover of less than $25 \%$ [48].

Mangrove ecosystem is one of the main ecosystems in coastal areas with high productivity that functions and supports the productivity of fishery resources. This high productivity is due to the ecological functions of mangroves, namely as nursery ground, feeding ground, and spawning ground. In the context of global warming, mangrove ecosystems act as carbon sinks and stores. Mangroves also play a role in the disaster mitigation process, especially against stream and waves, erosion, and coastal abrasion. The functional status of mangrove will be able to protect the movement of waves from sea to land [49]. If the productivity of these resource is damaged and critical, it will cause problems for human life and other natural environments. Assessment of the criticality and vulnerability of mangroves can be done by integrating biotic and abiotic factors together with human management component [50]. 


\subsection{Sustainable management of mangrove forest}

Mangrove forest has an important role in sustainable development in coastal areas [51]. Mangrove forest ecosystems have ecological, economic and physical or protective functions and benefits, currently the practice of mangrove logging affects the sustainability of mangrove forest ecosystems [52].

Sustainable management of mangrove forests requires planning that can ensure the continuity of functions and benefits for human life and other ecosystems. According to [53] the factors that influence the sustainability of mangrove forest management among others: the number of mangrove working groups, formal and informal rules, counseling on mangrove management, management institutions, application of institutional rules, role models, and community assistance in its management. Mangrove forest ecosystem, strengthening and increasing the participation of local communities in management activities, conflicts between the stakeholders and local wisdom.

The efforts to preserve and protect coastal areas from climate and tsunami can be started from local communities on the coast. Local governments that have close relation with coastal ecosystems in particular is village [49]. Furthermore, according to Feka [52] the existence of laws and various other local regulations on the mangrove forest area is needed and should highlight economic incentives that promote ecosystem conservation; the management systems with good governance indicators can measure and promote ecosystem health and stakeholder interests.

\section{METHODOLOGY}

\subsection{Research place}

The study was conducted in the Lower Lariang watershed between March to October in 2016 and 2017, which administratively located in North Mamuju Regency, West Sulawesi Province. Geographically, its located at position 00 51 '42.05 "- 1049 " 20.59 "N and 119016 " 40.73 "- 1190 51" 39.41 "E (Figure 1).

\subsection{Research procedure}

The research procedure was conducted in some stages. The first stage was to determine spatial location through the study of mangrove ecosystem maps using Landsat 7 ETM + Band 542 imagery to determine the downstream areas of the Lariang watershed which had vegetation covering and non-vegetation. The location determination results were delineated then a survey was conducted. The second step was the mangrove area calculating, both those that were still vegetation and nonvegetation. Mangrove area data collection was done by photogrammetric [54, 55] and terrestrial [56]. Photogrammetric method was conducted by the area calculating on a map / image Landsat 7 ETM + band 542. The measurements were made directly in the field for locations which difficult to detect an image or map extent because of its small location. The third stage was the inventory and identification of species, tree / pole potency and rejuvenation potency (saplings and seedlings) by sampling.

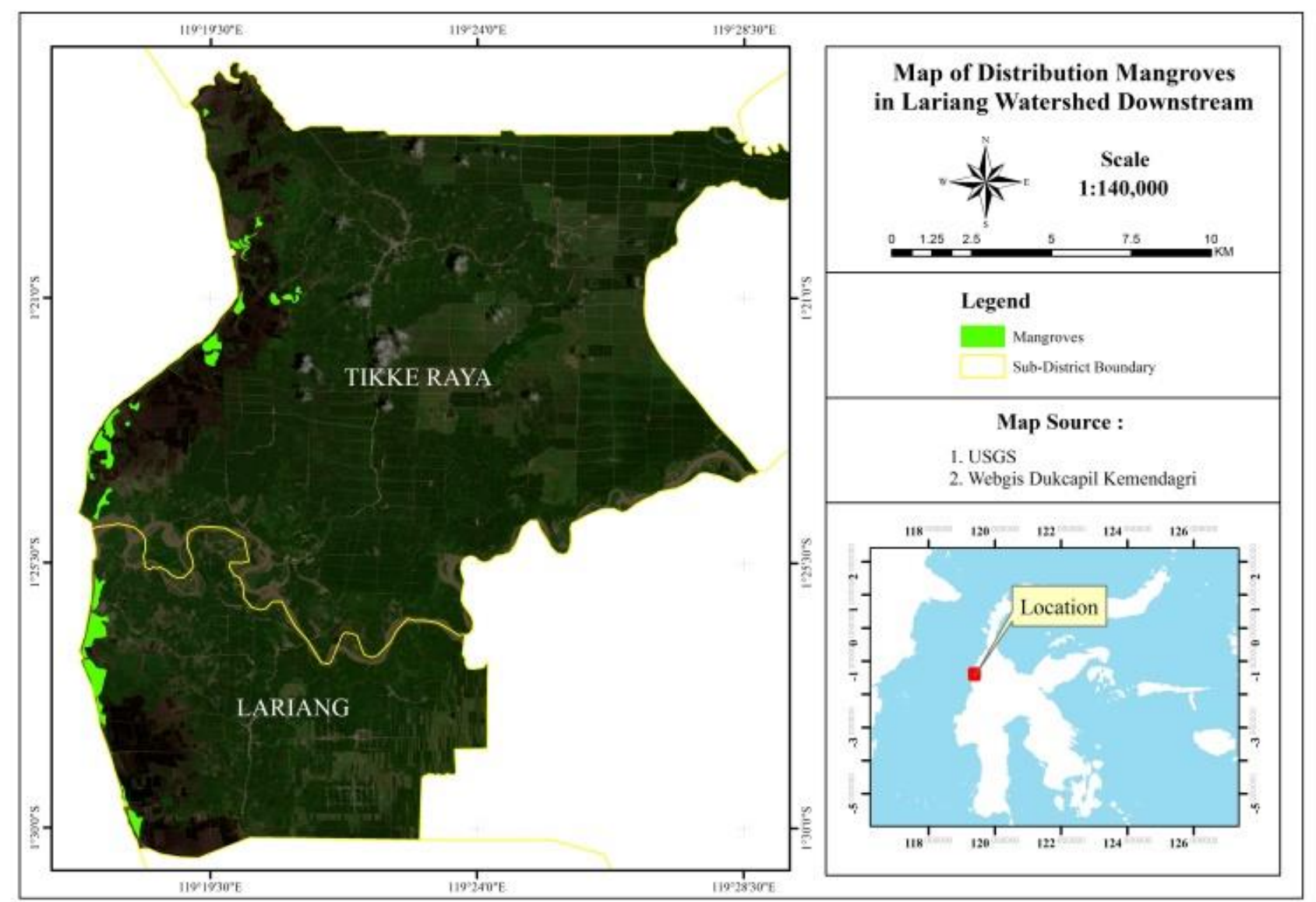

Figure 1. Research location 


\subsection{Measurement technique for vegetation and mangrove potency}

The measurement technique of vegetation potency and mangrove rejuvenation level was carried out sampling with 5\% sampling intensity using the line plot sampling method, and the spot check method was also used [57].

The determination to $5 \%$ was based on considerations of time, energy and very limited funds, bearing in mind which the object of activity covered the entire Lariang watershed downstream area. The sampling Intensity to $5 \%$ application was by determining the vegetation area in the mangrove area which based on scientific study that could represent the vegetation coverage (representative) condition. This method was carried out considering that most of the mangrove areas that would be sampled had been used for other uses, so that mangrove vegetation coverage was mostly only in the location spots form. The location determining as a sample object for the potency and species data collection was limited to areas, which were still vegetating mangroves that had 5 ha minimum area. It was sufficient to qualitatively collect data on species to determine the types of mangroves that grown in areas with less than 5 ha area, as well as to record the extent of damaged mangrove land.

In mangrove forest vegetation data collection using the line plot sampling method was done by drawing a plumb line with the size of the plot (sample plot) as follows: (1) the trees or poles level used to $10 \mathrm{~m} \times 10 \mathrm{~m}$ plot size; (2) saplings level to $5 \mathrm{~m} \times 5 \mathrm{~m}$ plot size; and (3) seedlings to $2 \mathrm{~m} \mathrm{x} 2 \mathrm{~m}$ plot sizes [58].

The spot check method was used to complete data or information on species composition, species distribution and general condition of mangrove forest ecosystems that were not observed in the plot line method. The results obtained were only descriptive by applying the spot check method.

Data collection on vegetation types in the field, local and scientific names were recorded in a tally sheet, while unknown species were sampled (specimens) to be identified at the UPT "Celebence UNTAD Herbarium Laboratory".

\subsection{Data analysis}

\subsubsection{Processing and analysis of satellite image data}

Land cover assessment in mangrove ecosystems that would be inventoried through satellite image analysis used the geographic information system (GIS) technology [59]. The maps form results of the mangrove land cover images were used to the field checking.

\subsubsection{Mangrove heading density}

Mangrove density assessment was approached manually and digitally. Both manual and digital methods would produce qualitative and quantitative densities with a certain level of accuracy. The canopy density assessment was conducted manually by direct observation in the field to determine the mangrove canopy density. Digital assessment using the normalized difference vegetation index (NDVI) formula was an assessment of the spectral reflection of green leaves from mangroves [60]. Based on the intensity value of the green leaf reflection, it was further explained as an indication of the mangrove canopy density level.

The canopy density classification with NDVI formula was done using image data processing program version 3.7 and map layout with GIS version 2.4. According to their characteristics, the red and infrared channels were very compatible with the sensitivity to the green reflection of the leaf chlorophyll content. Therefore, both channels were used to identify the leaves green reflection.

The NDVI analysis working principle was to measure the greenish intensity level. The greenish intensity in the Landsat image correlated with the vegetation canopy density level and for the detection of the greenness level in the image which correlated with the leaves chlorophyll content. The good band used was the infrared and red bands. The formulas used in NDVI were as follows:

$$
\mathrm{NDVI}=(\text { band } 4-\text { band } 3) /(\text { band } 4+\text { band } 3)
$$

The mangrove canopy densities classification was determined based on the NDVI values calculated range. The total density classification refersed to the Mangrove Inventory and Identification Guidebook, published by the MoF [61]. The class division was as follows:

a) Heavy canopy density $(0.43 \leq \mathrm{NDVI} \leq 1.00)$

b) Medium crown density $(0.33 \leq \mathrm{NDVI} \leq 0.42)$

c) Rare canopy density $(-1.00 \leq \mathrm{NDVI} \leq 0.32)$

\subsubsection{Soil resistance analysis to abrasion}

The soil resistance analysis to abrasion was carried out with the soil type and distribution approach. Information on soil type and distribution was obtained from the soil map / land system study area.

The soil characteristics/properties used for soil resistance analysis to abrasion were the soil physical properties in the soil texture form. Soil texture could be measured qualitatively in the field directly by selecting soil samples or by the land system map.

\subsubsection{Mangrove ecosystem critical assessment system}

Mangrove critical level assessment. In accordance with the criteria mentioned in the previous sub-chapter, an assessment of the mangrove ecosystems criticality level using GIS technology and remote sensing could be done with an assessment system (Table 1).

Based on Table 1, the Total Scoring Value $\left(\mathrm{TSV}_{1}\right)$ was calculated using the formula:

$$
\mathrm{TSV}_{1}=(\operatorname{LUT} \times 45)+(\text { HD } \times 35)+(\text { SRAA } \times 20)
$$

From $\mathrm{TSV}_{1}$, it could be determined the criticality mangrove ecosystems level:

Value 100-166: Severely damaged (very critical)

Value 167-233: Damaged (Critical)

Value 234-300: Not damaged (not critical).

Terrestrial Evaluation System (Field Survey). The land criticality assessment in mangrove ecosystems based on terrestrial methods (field survey) [62], carried out by mixed assessment system (Table 2).

The total scoring value $\left(\mathrm{TSV}_{2}\right)$ could be calculated using the formula:

$$
\begin{gathered}
\mathrm{TSV}_{2}=(\mathrm{CLU} \times 30)+(\mathrm{Tn} \times 25)+(\mathrm{R} \times 20)+(\mathrm{GLM} \\
\mathrm{x} 15)+(\mathrm{A} \times 10)
\end{gathered}
$$

Based on the $\mathrm{TSV}_{2}$, the critical level of mangrove land was 
classified:

Value 100-200: severely damaged (Very critical)

Value 201-300: damaged (Critical)

Value $>300$ : not damaged (not critical).

Type composition analysis. The types and potency analysis of mangrove forest vegetation was intended to determine the stands potency (trees/poles) and the regeneration level (saplings and seedlings), therefore the data was calculated / analyzed by calculating the amount (tree trunk/ha) (N), density (D), frequency (F) and type dominance (D). From this result, the Importance Value (IV) was calculated. The formula used was based on instructions [63]:

$$
\begin{gathered}
\text { IV: Relative density }+ \text { Relative dominance }+ \\
\text { Relative frequensi }
\end{gathered}
$$

where:

Relative density: Number of individuals/Number of individuals of all species

Relative dominance: Total basal area/ Total basal area of all species

Relative frequensi; Number of quadrants occurring/ Total number of quadrants

\begin{tabular}{|c|c|c|}
\hline Criteria & Rating & Information \\
\hline \multirow[t]{3}{*}{ Land Use Types (LUT) } & 45 & Score 3: wooded mangrove \\
\hline & & Score 2: Mixed ponds, plantations and $n$ \\
\hline & & Score 1: Settlement, Industry, Non-intercropping Ponds, rice fields, vacant land \\
\hline \multirow[t]{3}{*}{ Headline Density (HD) } & 35 & Score 3: Dense canopy density $(70-100 \%$ or $0.43 \leq \mathrm{NDVI} \leq 1.00)$ \\
\hline & & Score 2: Medium crown density $(50-69 \%$ or $0.33 \leq \mathrm{NDVI} \leq 0.42)$ \\
\hline & & Score 1: Canopy density was rare $(<50 \%$ or $-1.0 \leq$ NDVI $\leq) 0.32)$ \\
\hline \multirow{3}{*}{$\begin{array}{c}\text { Soil Resistance } \\
\text { Against Abrasion (SRAA) }\end{array}$} & 20 & Score 3: Soil type not sensitive to erosion (clay texture) \\
\hline & & Score 2: Erosion sensitive soil type (mixed texture) \\
\hline & & Score 1: Soil type very sensitive to erosion (sand texture) \\
\hline
\end{tabular}

Table 1. Criteria, weight and scores of mangrove ecosystem critical assessment scores

\begin{tabular}{|c|c|c|}
\hline Criteria & Rating & Rating Score \\
\hline \multirow{5}{*}{$\begin{array}{l}\text { Closure type and } \\
\text { land use } \\
\text { (CLU) }\end{array}$} & 30 & 5: Pure mangrove forest \\
\hline & & 4: Mangrove forest mixed with other forest stands \\
\hline & & 3: Mangrove forests were mixed with intercropping ponds or pure intercropping pond areas \\
\hline & & 2: Mangrove forest mixed with non-vegetation settlement land use, non-intercropping ponds and so on) \\
\hline & & 1: The area was not vegetated \\
\hline \multirow{5}{*}{$\begin{array}{l}\text { Trees number of / ha } \\
\text { (Tn) }\end{array}$} & 25 & 5: $\mathrm{N}=1500$ trees $/$ ha, evenly distributed $(\mathrm{F}=75 \%)$ \\
\hline & & 4: $N=1500$ trees $/$ ha, uneven $(F<75 \%)$ \\
\hline & & 3: $\mathrm{N}=100-1500$ trees $/$ ha, evenly distributed $(\mathrm{F}=75 \%)$ \\
\hline & & 2: $\mathrm{N}=1000-1500$ trees $/ \mathrm{ha}$, uneven $(\mathrm{F}<75 \%)$ \\
\hline & & $1: \mathrm{N}<1000$ trees / ha \\
\hline \multirow[t]{10}{*}{ Rejuvenation / ha (R) } & 20 & $5: \mathrm{N}=5000$ seedlings $/$ ha $(F=40 \%)$ \\
\hline & & $\mathrm{N}=2500$ saplings $/$ ha $(\mathrm{F}=60 \%)$ \\
\hline & & 4: $\mathrm{N}=4000-5000$ seedlings $/$ ha $(\mathrm{F}=40 \%)$ \\
\hline & & $\mathrm{N}=2000-2500$ saplings $/ \mathrm{ha}(\mathrm{F}=60 \%)$ \\
\hline & & 3: $\mathrm{N}=3000-4000$ seedlings $/$ ha $(\mathrm{F}=40 \%)$ \\
\hline & & $\mathrm{N}=1500-2000$ saplings $/ \mathrm{ha}(\mathrm{F}=60 \%)$ \\
\hline & & 2: $\mathrm{N}=2000-3000$ seedlings $/ \mathrm{ha}(\mathrm{F}=40 \%)$ \\
\hline & & $N=1000-1500$ saplings $/$ ha $(F=60 \%)$ \\
\hline & & 1: $\mathrm{N}<2000$ seedlings / ha $(\mathrm{F}=40 \%)$ \\
\hline & & $\mathrm{N}<1000$ saplings $/$ ha $(\mathrm{F}=60 \%)$ \\
\hline \multirow{5}{*}{$\begin{array}{l}\text { Greenline width } \\
\text { mangrove (GLM) }\end{array}$} & 15 & $5: \geq 100 \%$ \\
\hline & & 4: $80 \%-100 \%(130 \times$ difference in the highest and lowest tides $)$ \\
\hline & & 3: $60 \%-80 \%$ ( $130 \mathrm{x}$ difference in the highest and lowest tides) \\
\hline & & 2: $40 \%-60 \%$ (130 $\mathrm{x}$ difference in the highest and lowest tides) \\
\hline & & $1:<40 \%(130 \times$ difference in the highest and lowest tides $)$ \\
\hline \multirow[t]{5}{*}{ Abrasion rate $(\mathrm{A})$} & 10 & 5: $0-1 \mathrm{~m} /$ year \\
\hline & & 4: $1-2 \mathrm{~m} /$ year \\
\hline & & $3: 2-3 \mathrm{~m} /$ year \\
\hline & & 2: 3-5 m/ year \\
\hline & & 1:> $>\mathrm{m} /$ year \\
\hline
\end{tabular}

Table 2. Criteria, weight and assessment scores for terrestrial mangrove ecosystem land criticality

\section{RESULTS AND DISCUSSION}

\subsection{Extent, distribution and criticality of mangrove ecosystems}

From the Landsat 7 ETM + Band 542 imagery, NDVI value analysis, data and map analysis as well as the results of mangrove ecosystems survey in the Lariang watershed downstream reached an area of 577.07 ha (Table 3 ).

Table 3 and Figures 2 and 3, shown the mangroves distribution in the downstream Lariang watershed spread across two sub-district administration areas, namely Tikke 
Raya 340.86 ha, and Lariang 236.21 ha. When viewed from the condition of mangrove vegetation coverage according to its conditions, the condition of dense (uncritical) vegetation reached an area of 138.16 ha $(23.94 \%)$, followed by a rare (critical) condition of 286.63 ha $(49.67 \%)$, while a damaged condition (very critical) 152.28 ha $(26.39 \%)$. The large amount of mangrove obtained was due to the inclusion of nypa mangrove ecosystems (Nypa fruticans) in river estuaries at several other locations, as well as mangrove spots scattered in several locations downstream of the Lariang watershed.

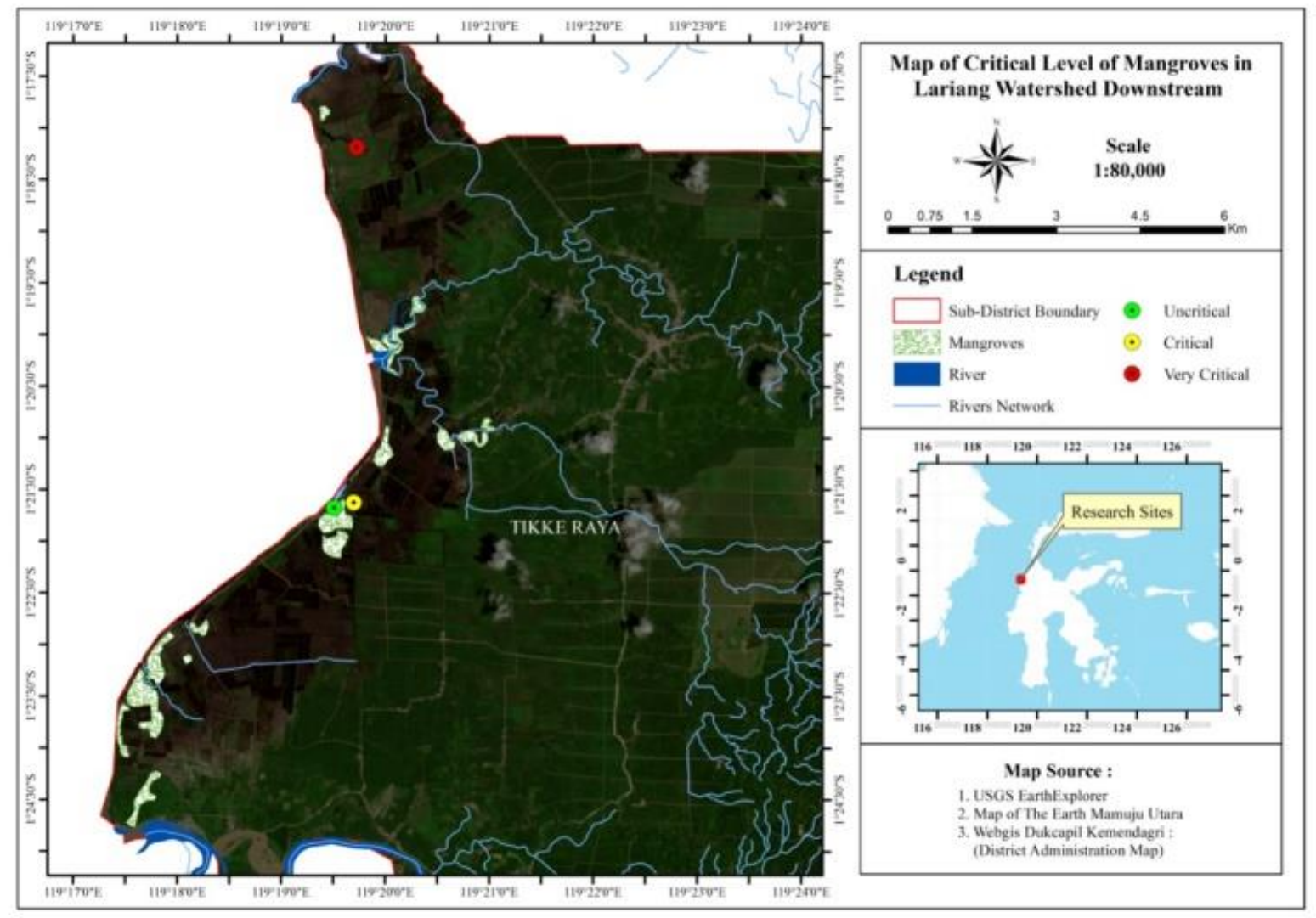

Figure 2. Critical level of mengroves in Lariang watershed downstream, sub-district Tikke Raya

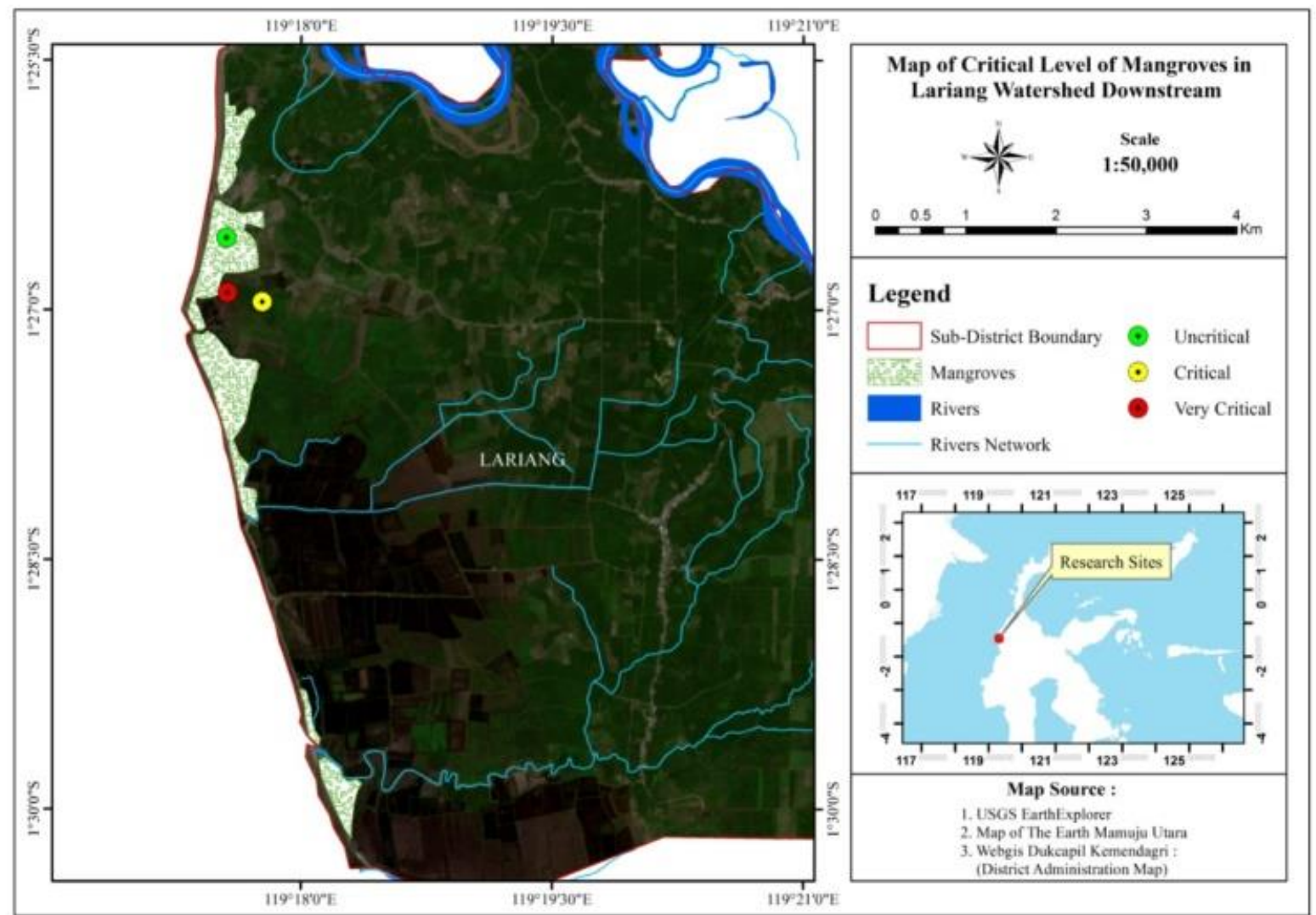

Figure 3. Critical level of mengroves in Lariang watershed downstream, sub-district Lariang 
The high level of criticality of mangroves is caused by exploitation and land conversion factors into residential areas and allotment of ponds, this can be found along the coast in the study area. This is in line with the statement [64], that in general critical mangrove land is caused by exploitation factors that are not environmentally friendly, such as logging for firewood. Conversion of ponds, settlements [65].

The mangrove vegetation coverage condition of each subdistrict area showed that the densest (uncritical) vegetation conditions in Tikke Raya sub-district with an area of 138.16 ha. For the highest rare (critical) vegetation coverage was the Lariang sub-district with an area of 212.75 ha. The coverage of damaged vegetation (very critical) was the highest Tikke Raya sub-district with an area of 128.82 ha. The high distribution of mangrove forest locations that were critical and very critical was caused by the large number of mangrove forest areas that had been converted into ponds, oil palm plantations, and settlements, as well as coastal abrasion. This was supported by Karuniastuti [66], that one of the causes of high damage to mangrove forests was the existence of coastal abrasion by the coastal erosion process due to the strong and destructive force of ocean waves and ocean currents. The damage was caused by human hands and natural phenomena [67].

The main mangrove cause critical and very critical was the mangrove forests conversion which did not pay attention to the environment factors. This was in accordance with the opinion [68-70] that the damage causes to mangrove forest ecosystems were included: mangrove forests conversion which it's not environmentally friendly, pollution and excessive logging and also the influence of the human factor.

\subsection{Mangrove forest composition and potential}

Classified mangrove species in Indonesia into three groups namely major mangrove flora species, minor mangrove flora and their associations, in this study limited to two groups types, namely the major flora species (true mangrove flora or true mangroves) and minor mangroves (following mangrove).

The research results based on the line plot sampling method, the mangroves composition and potency in the Lariang watershed downstream were presented in Table 4.

Table 4, generally mangrove forests in the Lower Lariang watershed could be divided into 3 zones; namely the front zone, the middle zone and the rear zone. The mangroves forefront was controlled by Rhizophora mucronata, rather into about 20-30 m Rhizophora mucronata had been mixed with several other mangrove species but still in relatively small quantities. These types were Rhizophora apiculata, Sonneratia alba, Bruguiera gymnorrhiza, these types were still unable to compete with the dominance of Rhizophora mucronata. The mangrove area central part was dominated by Bruguiera gymnorrhiza, Rhizophora apiculata and Rhizophora mucronata. The deepest part (middle) was dominated by Bruguiera gymnorrhiza mixed with Nifa fruticans especially in Lariang sub-district, and Rhizophora apiculata with larger tree diameters. The soil in mangrove forests was muddy and saturated with water and could be said to contain no oxygen, in this condition only a few plants could survive.

Table 3. Extent and distribution of mangrove ecosystem criticality level downstream of the Lariang watershed

\begin{tabular}{cccc}
\hline Sub-district & Coordinate point & Total Area (ha) & criticality level \\
\hline \multirow{3}{*}{ Tikke Raya } & $119^{\circ} 19^{\prime} 43.1^{\prime \prime} \mathrm{E} 1^{\circ} 18^{\prime} 11.3^{\prime \prime} \mathrm{S}$ & 138.16 & uncritical \\
& $119^{\circ} 19^{\prime} 30,5^{\prime \prime} \mathrm{E} 1^{\circ} 21^{\prime} 40.6^{\prime \prime} \mathrm{S}$ & 73.88 & critical \\
& $119^{\circ} 19^{\prime} 33.0^{\prime \prime} \mathrm{E} 1^{\circ} 21^{\prime} 38.4^{\prime \prime} \mathrm{S}$ & 128.82 & very critical \\
& $119^{\circ} 19^{\prime} 30.5^{\prime \prime} \mathrm{E} 1^{\circ} 21^{\prime} 40.6^{\prime \prime} \mathrm{S}$ & 0 & uncritical \\
Lariang & $119^{\circ} 19^{\prime} 41.6^{\prime \prime} \mathrm{E} 1^{\circ} 21^{\prime} 37.5^{\prime \prime} \mathrm{S}$ & 212.75 & critical \\
& $119^{\circ} 19^{\prime} 43.1^{\prime \prime} \mathrm{E} 1^{\circ} 18^{\prime} 11.3^{\prime \prime} \mathrm{S}$ & 23.46 & very critical \\
\hline
\end{tabular}

Table 4. Composition and potency of vegetation type and mangrove rejuvenation level

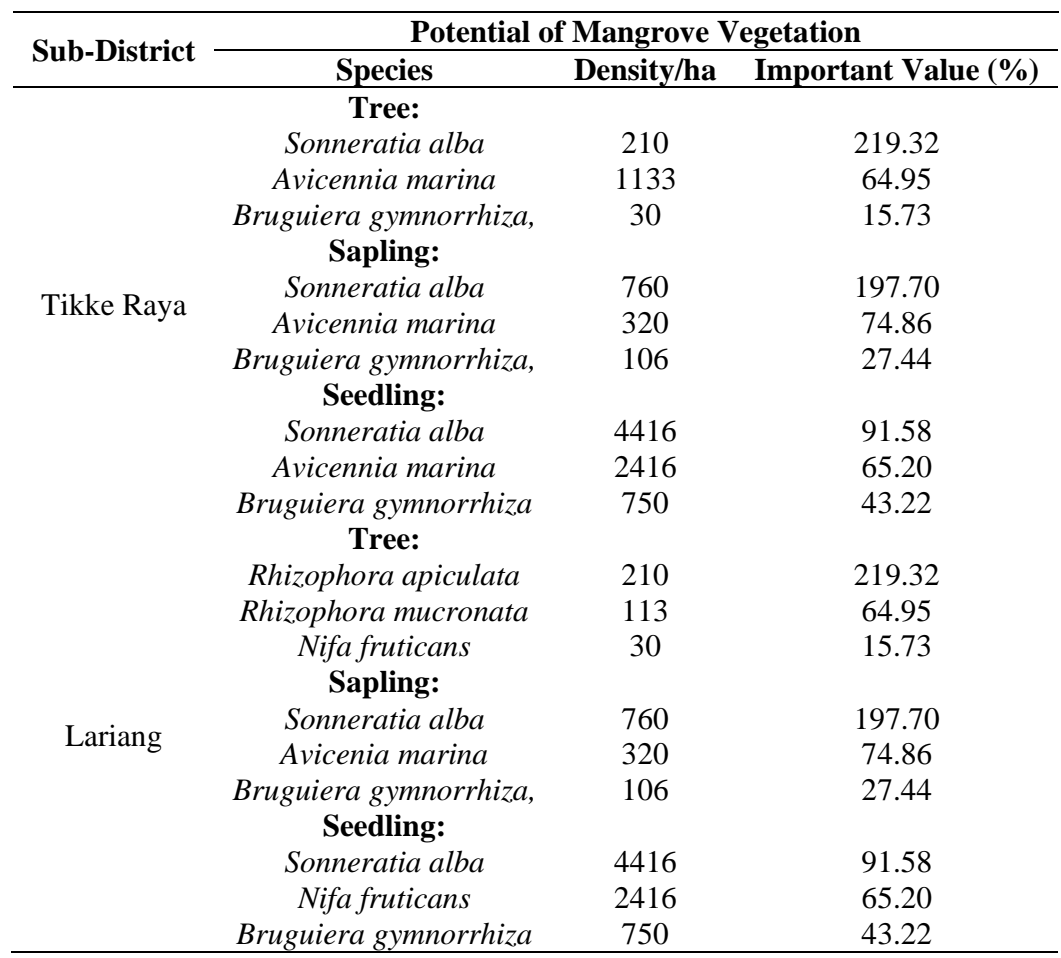


The dominant types were Sonneratia alba, Rhizophora apiculata, Avicenia marina (Table 4), This is because the sonneratia and avicenia and Rhizophora type mangroves were the first species to grow and develop at the research site. This is in line with research conducted [71], the first species to grow and develop in silt depositional habitats in coastal areas mixed with sand are Sonneratia and avicenia.

Most plants in mangrove forests downstream watershed Lariang, were "halophytes" which were plants that adapted to grow in salty habitats. Tropical mangroves often shown the species from wetlands zoning to drier land. The first zoning often was consisted by Rhizophora or Avicennia. When Rhizophora established itself in the lagoon a succession began, because the tree root began to catch mud particles and dead plants. This situation caused the accumulation of litter material which help to raise the soil surface when the Rhizophora plant died, where it was often replaced by more common terrestrial plants which were typical for the lagoon's environmental areas.

Based on zoning, in general the true mangrove flora types found in the lower Lariang watershed were Rhizophora spp., Bruguiera gymnorrhiza, Sonneratia alba, Avicennia marina. and Nypa fructicans. This mangrove flora type shown loyalty to mangrove habitat, had the ability to form pure stands and dominantly characterized community structures, its morphologically had special adaptive formed (root shape and viviparity) to the mangrove environment, and had physiological mechanisms to controlling the salt.

\section{CONCLUSIONS}

Downstream of the Laring watershed, there is an area of 286.63 ha or $49.67 \%$ of critical mangrove forest conditions, while the very critical condition is 152.28 ha or $26.39 \%$. Mangrove species that were still commonly found in research sites with good growing conditions, ranging from seedling, sapling to tree were dominated by Sonneratia alba, Avicennia marina, Rhizophora apiculata, and Rhizophora mucronata.

In each zone, the same species are still found due to natural factors and tides so that the fallen fruit will be carried away and grow in several mangrove zones.

The mangrove coastal areas replanting of the Lariang watershed downstream very necessary and urgent, especially those identified as being severely damaged or critically level.

The destruction of the mangrove forest ecosystem in the Lariang watershed is due to the conversion of land to pond uses, settlements, oil palm plantations and various other uses. To anticipate the level of mangrove damage, activities are needed to restore, maintain and improve the function of forests and mangrove forest lands in order to increase their carrying capacity, productivity and their role in maintaining life support systems through rehabilitation programs. Besides that, it is necessary to form regional regulations regarding efforts to preserve mangrove forests that bind between communities around the mangrove forest area, and prevent the destruction of mangroves from outside parties.

\section{ACKNOWLEDGMENT}

This research was conducted by the collaboration with BPDAS HL Lariang Mamasa, West Sulawesi through DIPA BA 029, therefore we thank the of BPDAS HL Lariang Mamasa Leadership, thank also the management of the
Wanacikal Nature Lover Student Forestry Faculty, Tadulako University who assisted in this research.

\section{REFERENCES}

[1] Vo, Q.T., Künzer, C., Vo, Q.M., Moder, F., Oppelt, N. (2012). Review of valuation methods for mangrove ecosystem services. Ecological Indicators, 23: 431-446. https://doi.org/10.1016/j.ecolind.2012.04.022

[2] Islam, M.M., Sunny, A.R., Hossain, M.M., Friess, D.A. (2018). Drivers of mangrove ecosystem service change in the Sundarbans of Bangladesh. Singapore Journal of Tropical Geography, 39(2): 244-265. https://doi.org/10.1111/sjtg.12241

[3] Leo, K.L., Gillies, C.L., Fitzsimons, J.A., Hale, L.Z., Beck, M.W. (2019). Coastal habitat squeeze: A review of adaptation solutions for saltmarsh, mangrove and beach habitats. Ocean \& Coastal Management, 175: 180-190. https://doi.org/10.1016/j.ocecoaman.2019.03.019

[4] Onyena, A.P., Sam, K. (2020). A review of the threat of oil exploitation to mangrove ecosystem: Insights from Niger Delta, Nigeria. Global Ecology and Conservation, 22: e00961. https://doi.org/10.1016/j.gecco.2020.e00961

[5] Giri, C., Ochieng, E., Tieszen, L.L., Zhu, Z., Singh, A., Loveland, T., Duke, N. (2011). Status and distribution of mangrove forests of the world using earth observation satellite data. Global Ecology and Biogeography, 20(1): 154-159. 8238.2010.00584.x

https://doi.org/10.1111/j.1466-

[6] Ilman, M., Wibisono, I.T.C., Suryadiputra, I.N.N. (2011) State of the art information on mangrove ecosystems in Indonesia. Wetlands International-Indonesia Programme, Bogor.

[7] Dat, P.T., Yoshino, K. (2013). Comparing mangrove forest management in Hai Phong City, Vietnam towards sustainable aquaculture. Procedia Environmental Sciences, $\quad 17$ : 109-118. https://doi.org/10.1016/j.proenv.2013.02.018

[8] Wu, Q., Tam, N.F., Leung, J.Y., Zhou, X., Fu, J., Yao, B., Xia, L. (2014). Ecological risk and pollution history of heavy metals in Nansha mangrove, South China. Ecotoxicology and Environmental Safety, 104: 143-151. https://doi.org/ 10.1016/j.ecoenv.2014.02.017

[9] Nfotabong-Atheull, A., Din, N., Dahdouh-Guebas, F. (2013). Qualitative and quantitative characterization of mangrove vegetation structure and dynamics in a periurban setting of Douala (Cameroon): An approach using air-borne imagery. Estuaries and Coasts, 36(6): 11811192. https://doi.org/10.1007/s12237-013-9638-8

[10] Satyanarayana, B., Mulder, S., Jayatissa, L.P., DahdouhGuebas, F. (2013). Are the mangroves in the GalleUnawatuna area (Sri Lanka) at risk? A social-ecological approach involving local stakeholders for a better conservation policy. Ocean \& Coastal Management, 71: 225-237. https://doi.org/10.1016/j.ocecoaman.2012.10.008

[11] Komiyama, A. (2014). Conservation of mangrove ecosystems through the eyes of a production ecologist. Reviews in Agricultural Science, 2: 11-20. https://doi.org/10.7831/ras.2.11

[12] Fusi, M., Beone, G.M., Suciu, N.A., Sacchi, A., Trevisan, M., Capri, E., Cannicci, S. (2016). Ecological status and sources of anthropogenic contaminants in mangroves of 
the Wouri River Estuary (Cameroon). Marine Pollution Bulletin, 109(2): 723-733. https://doi.org/10.1016/j.marpolbul.2016.06.104

[13] Bryan, K.R., Nardin, W., Mullarney, J.C., Fagherazzi, S. (2017). The role of cross-shore tidal dynamics in controlling intertidal sediment exchange in mangroves in Cù Lao Dung, Vietnam. Continental Shelf Research, 147: 128-143. https://doi.org/10.1016/j.csr.2017.06.014

[14] Sidik, F., Supriyanto, B., Krisnawati, H., Muttaqin, M.Z. (2018). Mangrove conservation for climate change mitigation in Indonesia. Wiley Interdisciplinary Reviews: $\begin{array}{lll}\text { Climate } & \text { Change, } & \text { 9(5): }\end{array}$ https://doi.org/10.1002/wcc.529

[15] Bryan-Brown, D.N., Connolly, R.M., Richards, D.R., Adame, F., Friess, D.A., Brown, C.J. (2020). Global trends in mangrove forest fragmentation. Scientific Reports, 10(1): 1-8. https://doi.org/10.1038/s41598-02063880-1

[16] Eddy, S., Milantara, N., Sasmito, S.D., Kajita, T., Basyuni, M. (2021). Anthropogenic drivers of mangrove loss and associated carbon emissions in South Sumatra, $\begin{array}{lll}\text { Indonesia. } & \text { Forests, } & 12(2) \text { : }\end{array}$ https://doi.org/10.3390/f12020187

[17] Gnansounou, S.C., Toyi, M., Salako, K.V., Ahossou, D.O., Akpona, T.J.D., Gbedomon, R.C., Kakaï, R.G. (2021). Local uses of mangroves and perceived impacts of their degradation in Grand-Popo municipality, a hotspot of mangroves in Benin, West Africa. Trees, Forests and People, 4: 100080. https://doi.org/10.1016/j.tfp.2021.100080

[18] Tokan, M.K., Imakulata, M.M., Neolaka, Y.A., Kusuma, H.S. (2018). Species diversity and vertical distribution of arboreal organisms on the Paradiso mangrove environment of Kupang Bay, East Nusa Tenggara, Indonesia. Asian Journal of Agriculture and Biology, 6: 535-542.

[19] Ariandi, D. (2019). Strategy of the Mangrove ecosystem management in efforts to combat abrasion in the Bantan District case of the Mangrove ecosystem in Teluk Papal Village, Bantan District, Bengkalis Regency, Indonesia. EurAsian Journal of BioSciences, 13(1): 75-82.

[20] Naharuddin, N., Malik, A., Rachman, I., Muis, H., Hamzari, H., Wahid, A. (2020). Land use planning for post-disaster soil liquefaction area based on erosion hazard index. International Journal of Design \& Nature and Ecodynamices (IJDNE), 15(4): 573-578. https://doi.org/10.18280/ijdne.150415

[21] Mubarokah, N., Rachman, L.M., Tarigan, S.D. (2020). Analysis of the carrying capacity of agricultural land of cibaliung watershed food crops, Banten Province. Jurnal Ilmu Pertanian Indonesia, 25(1): 73-80. https://doi.org/10.18343/jipi.25.1.73

[22] Rumenah, R.E.T., Priati, A. (2010). Potential Land and Critical Land. Faculty of Geography Gadjah Mada University, Yogyakarta.

[23] Razif, M., Farhan, I. (2017). A removal of Zn metal concentrate using Rhizophora apiculata mangrove plants. Asian J Agri \& Biol, 5: 328-336.

[24] Deng, H., He, J., Feng, D., Zhao, Y., Sun, W., Yu, H., Ge, C. (2020). Microplastics pollution in mangrove ecosystems: A critical review of current knowledge and future directions. Science of The Total Environment, 142041. https://doi.org/10.1016/j.scitotenv.2020.142041

[25] Santos, M.V.S., da Silva Júnior, J.B., Melo, V.M.M.,
Sousa, D.S., Hadlich, G.M., de Oliveira, O.M.C. (2021). Evaluation of metal contamination in mangrove ecosystems near oil refining areas using chemometric tools and geochemical indexes. Marine Pollution Bulletin, 166: 112179. https://doi.org/10.1016/j.marpolbul.2021.112179

[26] Xie, G., Zhang, J., Tang, X., Cai, Y., Gao, G. (2011). Spatio-temporal Heterogeneity of Water Quality (20102011) and Succession Patterns in Lake Bosten during the past 50 years. Journal of Lake Sciences, 23: 837-846. https://doi.org/10.18307/2011.0603

[27] Kibena, J., Nhapi, I., Gumindoga, W. (2014). Assessing the relationship between water quality parameters and changes in landuse patterns in the Upper Manyame River, Zimbabwe. Physics and Chemistry of the Earth, Parts A/B/C, 67: 153-163. https://doi.org/10.1016/j.pce.2013.09.017

[28] Cui, H., Zhou, X., Guo, M., Wu, W. (2016). Land use change and its effects on water quality in typical inland lake of arid area in China. Journal of Environmental Biology, 37(4): 603-609.

[29] Nouri, H., Mason, R.J., Moradi, N. (2017). Land suitability evaluation for changing spatial organization in Urmia County towards conservation of Urmia Lake. Applied Geography, 81: 1-12. https://doi.org/10.1016/j.apgeog.2017.02.006

[30] Santoso, N., Prasetyo, L.B. (2016). Mangrove ecosystem degradation level in Kaledupa Island, Wakatobi National Park. Jurnal Silvikultur Tropika, 6(3): 139-147. https://doi.org/10.29244/j-siltrop.6.3.\%25p

[31] Okoh, E., Yelebe, Z.R., Oruabena, B., Nelson, E.S., Indiamaowei, O.P. (2020). Clean-up of crude oilcontaminated soils: bioremediation option. International Journal of Environmental Science and Technology, 17(2): 1185-1198. https://doi.org/10.1007/s13762-01902605-y

[32] Shahrbabak, S.M., Erfani, M., Ardakani, T. (2021). Variety of gastropods biodiversity associated with natural and anthropogenic factors in Mangrove Forests located at border of Iran and Pakistan. International Journal of Environmental Science and Technology, 18(4): 989-996. https://doi.org/10.1007/s13762-02002887-7

[33] Sillanpää, M., Vantellingen, J., Friess, D.A. (2017). Vegetation regeneration in a sustainably harvested mangrove forest in West Papua, Indonesia. Forest Ecology and Management, 390: 137-146. https://doi.org/10.1016/j.foreco.2017.01.022

[34] Minchinton, T.E., Shuttleworth, H.T., Lathlean, J.A., McWilliam, R.A., Daly, T.J. (2019). Impacts of cattle on the vegetation structure of mangroves. Wetlands, 39(5): 1119-1127. https://doi.org/10.1007/s13157-019-01143-0

[35] Rasquinha, D.N., Mishra, D.R. (2021). Impact of wood harvesting on mangrove forest structure, composition and biomass dynamics in India. Estuarine, Coastal and Shelf $\quad$ Science, 106974. https://doi.org/10.1016/j.ecss.2020.106974

[36] Sheng, Y.P., Zou, R. (2017). Assessing the role of mangrove forest in reducing coastal inundation during major hurricanes. Hydrobiologia, 803(1): 87-103. https://doi.org/10.1007/s10750-017-3201-8

[37] Taureau, F., Robin, M., Proisy, C., Fromard, F., Imbert, D., Debaine, F. (2019). Mapping the mangrove forest canopy using spectral unmixing of very high spatial 
resolution satellite Images. Remote Sensing, 11(3): 367. https://doi.org/10.3390/rs11030367

[38] Chakraborty, S., Saha, S.K., Selim, S.A. (2020). Recreational services in tourism dominated coastal ecosystems: Bringing the non-economic values into focus. Journal of Outdoor Recreation and Tourism, 30: 100279. https://doi.org/10.1016/j.jort.2020.100279

[39] Idrus, A.A., Syukur, A., Zulkifli, L. (2019). The livelihoods of local communities: Evidence success of mangrove conservation on the coastal of East Lombok Indonesia. In AIP Conference Proceedings, 2199(1): 050010. https://doi.org/10.1063/1.5141308

[40] Malik, A., Fensholt, R., Mertz, O. (2015). Mangrove exploitation effects on biodiversity and ecosystem services. Biodiversity and Conservation, 24(14): $3543-$ 3557. https://doi.org/10.1007/s10531-015-1015-4

[41] Friess, D.A. (2016). Mangrove forests. Current Biology, 26(16): R746-R748.

[42] Grebner, D.L., Bettinger, P., Siry, J.P., Boston, K. (2021). Introduction to Forestry and Natural Resources. Academic Press.

[43] Bünemann, E.K., Bongiorno, G., Bai, Z., Creamer, R.E., De Deyn, G., de Goede, R., Brussaard, L. (2018). Soil quality-A critical review. Soil Biology and Biochemistry, 120: 105-125. https://doi.org/10.1016/j.soilbio.2018.01.030

[44] Santos, R.M.B., Fernandes, L.S., Varandas, S.G.P., et al. (2015). Impacts of climate change and land-use scenarios on Margaritifera margaritifera, an environmental indicator and endangered species. Science of the Total Environment, 511: 477-488. https://doi.org/10.1016/j.scitotenv.2014.12.090

[45] Koop, S.H., van Leeuwen, C.J. (2015). Assessment of the sustainability of water resources management: A critical review of the city blueprint approach. Water Resources Management, $\quad 29(15)$ : $\quad 5649-5670$. https://doi.org/10.1007/s11269-015-1139-z

[46] López-Portillo, J., Lewis, R.R., Saenger, P., et al. (2017). Mangrove Forest Restoration and Rehabilitation. In Mangrove Ecosystems: A Global Biogeographic Perspective. Springer, Cham, 301-345.

[47] Temperton, V.M., Buchmann, N., Buisson, E., et al. (2019). Step back from the forest and step up to the Bonn Challenge: How a broad ecological perspective can promote successful landscape restoration. Restoration Ecology, 27(4): 705-719. https://doi.org/10.1111/rec.12989

[48] Altieri, M.A. (2018). Agroecology: The Science of Sustainable Agriculture. CRC Press.

[49] Agus, S.B., Rusrita, G., Ramadhani, R.A., Akmal, S.G. (2020). Mangrove governance: Establish a new paradigm of mangrove management "from village to the world". In IOP Conference Series: Earth and Environmental Science, 550(1): 012012. https://doi.org/10.1088/1755$1315 / 550 / 1 / 012012$

[50] Ellison, J.C. (2015). Vulnerability assessment of mangroves to climate change and sea-level rise impacts. Wetlands Ecology and Management, 23(2): 115-137. https://doi.org/10.1007/s11273-014-9397-8

[51] Chow, J. (2018). Mangrove management for climate change adaptation and sustainable development in coastal zones. Journal of Sustainable Forestry, 37(2): 139-156.

https://doi.org/10.1080/10549811.2017.1339615
[52] Feka, Z.N. (2015). Sustainable management of mangrove forests in West Africa: A new policy perspective? Ocean \& Coastal Management, 116: 341-352. https://doi.org/10.1016/j.ocecoaman.2015.08.006

[53] Kusmana, C., Hidayat, A., Noorachmat, B.P. (2020). Sustainable status of mangrove forest ecosystem management in Langsa City, Aceh, Indonesia. Aquaculture, Aquarium, Conservation \& Legislation, 13(1): 125-136.

[54] Zhang, W., Li, X., Xiao, W. (2018). Decision tree repository and rule set based Mingjiang river estuarine wetlands classifaction. International Archives of the Photogrammetry, Remote Sensing and Spatial Information Sciences, 42(3): 2635-2641. https://doi.org/10.5194/isprs-archives-XLII-3-26352018

[55] Julzarika, A., Anggraini, N., Adawiah, S.W. (2019). Detection of True mangroves in Indonesia using satellite remote sensing. Journal of Environmental Analysis and Progress, 4(3): 157-167. https://doi.org/10.24221/jeap.4.3.2019.2488.157-167

[56] Hamzah, M.L., Amir, A.A., Maulud, K.N.A., Sharma, S., Mohd, F.A., Selamat, S.N., Begum, R.A. (2020). Assessment of the Mangrove forest changes along the Pahang coast using remote sensing and GIS technology. Journal of Sustainability Science and Management, 15(5): 43-58.

[57] Winata, A., Yuliana, E., Rusdiyanto, E. (2017). Diversity and natural regeneration of mangrove vegetation in the tracking area on Kemujan Island Karimunjawa National Park, Indonesia. Advances in Environmental Sciences, 9(2): 109-119.

[58] Lestyaningrum, R.A., Mahmudi, M., Harahab, N. (2017). The biodeversity of mangrove in ngantep coastal, Malang district. Indonesian Journal of Environment and Sustainable Development, 8(1).

[59] Saffawati, T.N., Ismail, T., Kassim, N.F., Rahman, A.A., Hamid, S.A., Yahya, K., Webb, C.E. (2019). The application of geographic information system (GIS) to assess the population abundance of Aedes albopictus (Skuse) in mangrove forests of Penang, Malaysia. International Journal of Mosquito Research, 6(1): 50-54

[60] Flores-Cárdenas, F., Millán-Aguilar, O., Díaz-Lara, L., Rodríguez-Arredondo, L., Hurtado-Oliva, M.Á., Manzano-Sarabia, M. (2018). Trends in the normalized difference vegetation index for mangrove areas in northwestern Mexico. Journal of Coastal Research, 34(4): 877-882. https://doi.org/10.2112/JCOASTRESD-17-00022.1

[61] MoF. (2005). Guidelines for Inventory and Identification of Critical Mangrove Land. MoF, Jakarta.

[62] Sofian, A., Kusmana, C., Fauzi, A., Rusdiana, O. (2019). Ecosystem services-based mangrove management strategies in Indonesia: A review. Aquaculture, Aquarium, Conservation \& Legislation, 12(1): 151-166.

[63] Rachman, A., Saharjo, B.H., Intan, E., Putri, K. (2020). Forest and land fire prevention strategies in the forest management Unit Kubu Raya, South Ketapang, and North Ketapang in West Kalimantan Province. Jurnal Ilmu Pertanian Indonesia, 25(2): 213-223. https://doi.org/10.18343/jipi.25.2.213

[64] Karim, A., Fazlina, Y.D., Fathanah, N. (2020). Evaluation of the critical level of mangrove ecosystems using Spatial Technology in East Aceh Coastal Areas. In 
IOP Conference Series: Earth and Environmental Science, 425(1): 012015.

[65] Hariyadi, S., Madduppa, H. (2018). Condition and mangrove density in Segara Anakan, Cilacap Regency, Central Java Province, Indonesia. Aquaculture, Aquarium, Conservation \& Legislation, 11(4): 10551068.

[66] Karuniastuti, N. (2013). The role of mangrove forests for the environment. Forum Manajemen, 6: 1-10.

[67] DasGupta, R., Shaw, R. (2013). Cumulative impacts of human interventions and climate change on mangrove ecosystems of South and Southeast Asia: an overview. Journal of Ecosystems, 13: 1-15. https://doi.org/10.1155/2013/379429

[68] Utomo, B., Budiastuty, S., Muryani, C. (2018). Mangrove forest management strategy in tanggul tlare village, Kedung District, Jepara Regency. Jurnal Ilmu Lingkungan, https://doi.org/10.14710/jil.15.2.117-123

[69] Obade, P.T., Koedam, N., Soetaert, K., Neukermans, G., Bogaert, J., Nyssen, E., Dahdouh-Guebas, F. (2008). Impact of anthropogenic disturbance on a mangrove forest assessed by a 1d cellular automaton model using lotka-volterra-type competition. International Journal of Design \& Nature and Ecodynamics, 3(4): 297-320.

[70] Getzner, M., Islam, M.S. (2013). Natural resources, livelihoods, and reserve management: A case study from Sundarbans mangrove forests, Bangladesh. International Journal of Sustainable Development and Planning, 8(1): 75-87.

[71] Yapanto, L.M., Doni Nurdiansah, D.P.P.M., Noho, Y., Paramata, A., Musa, D.T. (2021). Mangroves and different health conditions of mangrove forests in North Lembeh waters. Annals of the Romanian Society for Cell Biology, 25(6): 3016-3025. 